\title{
Nebivolol - A Review
}

\section{UZZAL KANTI DAS ${ }^{1}$, SYED ALI AHSAN ${ }^{2}$, MOHAMMAD SALMAN ${ }^{3}$, MOHAMMAD FERDOUS UR RAHAMAN ${ }^{4}$, MD. MIZANUR RAHMAN KHAN ${ }^{4}$, MD.ASHRAF UDDIN SULTAN ${ }^{2}$, MD. ATIQUR RAHMAN ${ }^{4}$}

${ }^{1}$ Department of Medicine, Chittagong Medical College Hospital, Chittagong, ${ }^{2}$ Department of Cardiology, Bangabandhu Sheikh Mujib Medical University (BSMMU), Dhaka, ${ }^{3}$ Anwer Khan Modern Medical College, Dhaka, ${ }^{4}$ Department of Medicine, Bangabandhu Sheikh Mujib Medical University (BSMMU), Dhaka.

Address for correspondence: $\quad$ Dr. Mohammad Salman, Assistant Professor, Anwer Khan Modern Medical College, Dhaka, E-mail: drmdsalman@gmail.com

\begin{abstract}
Nebivolol is a vasodilating $\beta$-blocker, which can be distinguished from other $\beta$-blockers by its haemodynamic profile. It combines $\beta$-adrenergic blocking activity with a vasodilating effect mediated by the endothelial $L$ arginine nitric oxide (NO) pathway. The blood pressure lowering effect of nebivolol is linked to a reduction in peripheral resistance and an increase in stroke volume and preservation of cardiac output. Clinical trials have demonstrated that nebivolol reduces blood pressure similarly to atenolol, bisoprolol, amlodipine, nifedipine, lisinopril, and hydrochlorothiazide. The tolerability of nebivolol is similar to or better than that of these agents. In general, response rates to treatment are higher and the frequency and severity of adverse events are either comparable or lower with nebivolol. Endothelium-derived NO is important in the regulation of large arterial stiffness, which in turn is a major risk factor for cardiovascular disease. Therefore, antihypertensive drugs, such as nebivolol, that also improve endothelial function and decrease arterial stiffness, may contribute to a reduction in cardiovascular risk.
\end{abstract}

Key words: Vasodilating $\beta$-blocker, nitric oxide (NO), peripheral resistance, arterial stiffness

Hypertension is one of the major risk factor for cardiovascular disease especially ischemic heart disease and stroke. It impairs left ventricular systolic and diastolic function and thus becomes an important precursor of heart failure. A large number of cardiac death and hospitalization occurring in the elderly are due to hypertension. Pathophysiology of hypertension is characterized by endothelial dysfunction with impaired production of nitric oxide resulting in decreased vasodilatation. Nebivolol, a new highly selective beta blocker and antihypertensive agent has the potential to improve the endothelial dysfunction and improved nitric oxide production. Clinical studies have shown that it is effective and safe in controlling hypertension and chronic heart failure.

Beta-blockers are frequently considered an effective and safe option for the first line treatment of hypertension. ${ }^{1}$ However, recently they are no longer be considered for the first line therapy in uncomplicated hypertension because of unfavorable morbidity data. ${ }^{2}$ Rather they should be used in post myocardial infarction, heart failure and atrial fibrillation and may be used in uncomplicated hypertension as a third or fourth line therapy. ${ }^{3}$ Evidence shows that beta-blockers with or without diuretics were associated with greater number of cases of new onset diabetes mellitus than regimens based on ACE inhibitors, angiotensin receptor blockers or calcium antagonists. ${ }^{4}$ In addition ASCOT (Anglo Scandinavian Cardiac Outcome Trial) demonstrated an excess of $24 \%$ cardiovascular deaths, $14 \%$ cardiac events and $23 \%$ cerebrovascular events associated with beta blocker atenolol ( \pm diuretic) and $30 \%$ new onset diabetes compared with calcium antagonist ( \pm ACE inhibitors) based therapy. ${ }^{5}$

Nebivolol, a new third generation beta-blocker that differs from other beta-blockers such as atenolol, metoprolol or bisoprolol in that it is a highly selective beta-blocker with additional endothelial nitric oxide (NO)- mediated vasodilating activity. ${ }^{6}$ In addition, it has anti-oxidant properties and favorable metabolic profile on both carbohydrate and lipid metabolism. ${ }^{7}$ It significantly reduces triglycerides, total and LDL cholesterol. ${ }^{8}$ It does not reduce insulin sensitivity like atenolol and it has no effect in the incidence of new onset of diabetes mellitus ${ }^{9}$. Fatigue, depression, bradycardia, erectile dysfunction worsening of cardiac contractility and bronchospasm are very low with nebivolol. ${ }^{10}$

Nebivolol is a new beta blocker. It is a racemic mixture of $d-$ Nebivolol and l-Nebivolol. The former (d-Nebivolol) has selective ß1-receptor blocking activity and the later (1Nebivolol) has vasodilating property. Unlike other third generation ß-blockers, such as labetolol, carvedilol and bucindolol which mediate vasodilatory effect through alpha-1 adrenoreciptor antagonism, nebivolol mediate 
endothelium-dependent arterial and venous dilatation via the L-agrinine-nitric oxide (NO) dependent pathway. (Lagrinine is a precursor of nitric oxide). ${ }^{11,12}$ Overall antihypertensive effect of nebivolol is exerted by the combination of the activity of both enantiomers. Nebivolol also improves vascular endothelial function. It increases NO-production via stimulation of endothelial NOsynthetase (eNOS) and reduces oxidative inactivation of NO. ${ }^{13}$ Stimulation of eNOS by nebivolol might reduce circulating level of asymmetric dimethylarginine (ADMA), a potent inhibitor of eNOS. It may also stimulate serotonin 5HTA receptors, which in turn stimulate eNOS activity. It decreases oxidative stress in essential hypertension and increases NO by reducing its oxidative inactivation. ${ }^{13}$ Study also shows that nebivolol significantly increased oxidative stress, HOMA index and plasma soluble pselectin levels, and increased adiponectin levels in hypertensive patients treated with nebivolol. ${ }^{14}$ It also possesses anti-proliferative properties that are potentially useful in hypertensive patients.

Comparing with other ß-blockers Nebivolol is as effective as atenolol in reducing blood pressure, but has a more homogeneous effect over 24 hours. ${ }^{15}$ Moreover it has been associated with a longer reduction in cardiac index and decline in mean pulmonary artery pressure and pulmonary wedge pressure both at rest and with exercise. ${ }^{16}$
It does not reduce exercise tolerance, because it does not inhibit the formation of free fatty acids which are a substance for energy expenditures, to the same extent as other ß-blockers. ${ }^{17,18}$

A number of clinical trials have been carried out to see the efficacy and tolerability in patients with hypertension and chronic heart failure. Table-1 shows the summery of clinical studies in hypertensive patients comparing nebivolol with placebo and other beta-blockers. The anti hypertensive effect of nebivolol at different doses (0.5-10 mg per day) was greater than placebo, but similar with other betablockers with better tolerability profile. A large multi center, randomized, double-blind, placebo controlled, doseranging study of the efficacy and tolerability of nebivolol recruited 509 hypertensive (diastolic blood pressure e”95mmHg) patients were allocated to receive nebivolol or placebo once daily for four weeks. Nebivolol $2.5 \mathrm{mg}$ ( $\mathrm{n}=85), 5 \mathrm{mg}(\mathrm{n}=86)$, and $10 \mathrm{mg}(\mathrm{n}=84)$ were associated with significant, dose dependent decreases in systolic blood pressure and diastolic blood pressure compared with placebo ( $n=84$ ) (all, $p<0.05$ vs baseline vs placebo). The efficacy and tolerability of nebivolol were also compared with lisinopril, enalapril, telmisartan, nifedipine and amlodipine in randomized, double-blind clinical trials. The efficacy of nebivolol in reducing blood pressure was comparable with these drugs and well tolerated. ${ }^{22}$

Table-I

Clinical studies of Nebivolol in the management of hypertension.

\begin{tabular}{|c|c|c|c|c|c|c|}
\hline Authors/Design & Population & $\begin{array}{l}\text { No of } \\
\text { patients }\end{array}$ & Regimens & Duration & BP Reduction, mm Hg & Adverse Effects \\
\hline $\begin{array}{l}\text { Van Nueten et al MC, } \\
\mathrm{R}, \mathrm{DB}, \mathrm{PC}\end{array}$ & $\begin{array}{l}\text { Essential HTN (DBP } \\
95 \mathrm{~mm} \mathrm{Hg})\end{array}$ & 509 & $\begin{array}{l}\text { Neb: } 0.51,2.5 \\
5 \text {, or } 10 \mathrm{mg} / \mathrm{d} \\
\text { Pla }\end{array}$ & $4 w k$ & $\begin{array}{l}\left.\text { Supine (at } \mathrm{C}_{\min }\right)^{-} \text {Nebi } \\
\text { 0.5mg:-2.9/-4.0; Nebi } \\
\text { 1mg:-6.8/-6.0; Nebi } 2.5 \\
\text { mg: }-8.6 /-7.1 \quad(P<0.05 \mathrm{vs} \\
\text { baseline); Nebi } 5 \mathrm{mg}:- \\
9.2 /-9.2 \quad(P<0.05 \mathrm{vs} \\
\text { baseline); Nebi } 10 \mathrm{mg}:- \\
8.2 /-10.2 \quad(P<0.05 \quad \mathrm{vs} \\
\text { baseline); Pla: }-3.1 /-3.3\end{array}$ & 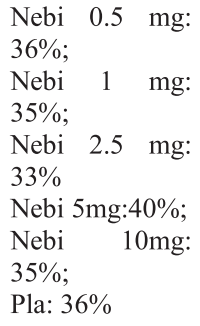 \\
\hline $\begin{array}{l}\text { Van Nuteen et al R, DB, } \\
\text { APC, PG }\end{array}$ & $\begin{array}{l}\text { Mild to moderate HTN } \\
\text { (DBP } 95-115 \mathrm{~mm} \mathrm{Hg} \text { ) }\end{array}$ & 364 & $\begin{array}{l}\text { Nebi } 5 \mathrm{mg} / \mathrm{d} \\
\text { Aten } 50 \mathrm{mg} / \mathrm{d} \\
\text { Pla }\end{array}$ & $4 w k$ & $\begin{array}{l}\text { Nebi: }-16 /-13(p<0.001 \text { vs } \\
\text { Pla); Aten: }-14 /-12 \\
(\mathrm{p}<0.001 \text { vs Pla }) ; \text { Pla: }-6 /- \\
3\end{array}$ & $\begin{array}{l}\text { Nebi: } \quad 29 \% \\
\text { Aten: } 31 \% \text {; Pla: } \\
25 \%\end{array}$ \\
\hline Grassi et al $\mathrm{R}, \mathrm{DB}$ & $\begin{array}{l}\text { Mild to moderate HTN } \\
(\text { DBP }>90 \mathrm{~mm} \mathrm{Hg}, \mathrm{SBP} \\
>140 \mathrm{~mm} \mathrm{hg})\end{array}$ & 205 & $\begin{array}{l}\text { Nebi } 5 \mathrm{mg} / \mathrm{d} \\
\text { Aten } 100 \mathrm{mg} / \mathrm{d}\end{array}$ & $12 w k$ & $\begin{array}{l}\text { Nebi: }-19.1 /-14.8 \text {; Aten: - } \\
18.2 /-14.3\end{array}$ & $\begin{array}{l}\text { Nebi: } \quad 20 \% \text {; } \\
\text { Aten: } 41 \%(P< \\
0.001 \text { vs Nebi })\end{array}$ \\
\hline Czuriga et al R, SB & $\begin{array}{l}\text { Mild to moderate HTN } \\
\text { (DBP } 95-110 \mathrm{~mm} \mathrm{hg} \text {, } \\
\text { SBP } 180 \mathrm{~mm} \mathrm{Hg} \text { ) }\end{array}$ & 273 & $\begin{array}{l}\text { Nebi } 5 \mathrm{mg} / \mathrm{d} \\
\text { Biso } 5 \mathrm{mg} / \mathrm{d}\end{array}$ & $4 w k$ & $\begin{array}{l}\text { Nebi: } \quad-20.5 /-15.7 ; \text { Biso:- } \\
20.0 /-16.0\end{array}$ & $\begin{array}{l}\text { Nebi: } \quad 5.8 \% \text {; } \\
\text { Biso: } 8.9 \%\end{array}$ \\
\hline
\end{tabular}


Table-II

Clinical studies of Nebivolol in the management of heart failure

\begin{tabular}{|c|c|c|c|c|c|c|}
\hline $\begin{array}{l}\text { Authors/ } \\
\text { Design }\end{array}$ & Population & $\begin{array}{l}\text { No. of } \\
\text { Patients }\end{array}$ & Regimens & Duration & $\begin{array}{l}\text { Results for Primary } \\
\text { End Points }\end{array}$ & Adverse Effects \\
\hline $\begin{array}{l}\text { Flather et al R, DB, } \\
\text { PC }\end{array}$ & $\begin{array}{l}\text { Patients aged } \\
70 \text { y with } \\
\text { chronic stable } \\
\text { clinical HF }\end{array}$ & 2128 & $\begin{array}{l}\text { Nebi } 1.25-10 \\
\mathrm{mg} / \mathrm{d} \backslash \\
\mathrm{Pla}\end{array}$ & $12 \mathrm{mo}$ & $\begin{array}{l}\text { All-cause mortality or } \\
\text { CV hospitalization: - } \\
14 \% \text {, Nebi vs Pla (HR } \\
=0.86 ; 95 \% \text { CI, } 0.74- \\
0.99 ; P=0.039)\end{array}$ & $\begin{array}{ll}\text { Bradycardia: } & 11.1 \% \\
\text { Nebi and } 2.6 \% \mathrm{Pla}\end{array}$ \\
\hline $\begin{array}{l}\text { Patrianakos et al R, } \\
\text { DB }\end{array}$ & $\begin{array}{lr}\text { Mild } & \text { to } \\
\text { moderate } & \text { HF } \\
\text { (NYHA Class 11- } \\
111), & \text { LVEF } \\
<45 \% & \end{array}$ & 72 & $\begin{array}{lr}\text { Nebi } & 1.25-5 \\
\mathrm{mg} / \mathrm{d} & \text { Carv } \\
3.125-25 & \mathrm{mg} \\
\mathrm{BID} & \end{array}$ & $12 \mathrm{mo}$ & $\begin{array}{l}\text { LVEF: }+6.1 \% \text { Nebi vs } \\
+8.8 \% \text { Carv }(P=0.02, \\
\text { Nebi vs Carv; both, } P \\
<0.05 \text { vs baseline })\end{array}$ & $\begin{array}{l}\text { Discontinuation rate } \\
\text { due to AEs: } 16.7 \% \\
\text { Nebi and } 8.6 \% \text { Carv } \\
\text { Exercise capacity: } \\
+80 \text { vs }+110 \text { min, } \\
\text { respectively ( } P< \\
0.01, \text { Nebi vs Carv; } \\
\text { both, } P<0.01 \text { vs } \\
\text { baseline) }\end{array}$ \\
\hline Edes et al. (ENECA) & $\begin{array}{l}\text { Age >65y; } \\
\text { NYHA class II- } \\
\text { IV CHF; } \\
35 \%\end{array}$ & $\begin{array}{l}134 \\
126\end{array}$ & $\begin{array}{l}\text { NEB } \\
\text { PL }\end{array}$ & $8 \mathrm{mo}$ & $\begin{array}{l}\text { LVEF: }+6.51 \% \\
\text { (Nebi)vs } \\
+3.97 \%(\mathrm{PL}) \\
\text { Both, } P<0.05 \text { vs } \\
\text { baseline }\end{array}$ & \\
\hline $\begin{array}{l}\text { Ghio et al. (SENIORS } \\
\text { echocardiographic } \\
\text { substudy) }\end{array}$ & $\begin{array}{l}\text { Age } 70 y ; \\
\text { NYHA class I- } \\
\text { IV CHF }^{b}\end{array}$ & $\begin{array}{l}27 \\
(\mathrm{LVEF} 35 \%) \\
16 \\
27 \quad(\mathrm{LVEF} \\
>35 \%) \\
34\end{array}$ & $\begin{array}{l}\text { NEB } \\
\text { PL } \\
\text { NEB } \\
\text { PL }\end{array}$ & $12 \mathrm{mo}$ & $\begin{array}{l}+4.6 \% \\
-0.1(\mathrm{p}<0.01 \mathrm{vs} \text { pla }) \\
1.0 \\
1.2\end{array}$ & \\
\hline
\end{tabular}

$\mathrm{R}=$ randomized $\mathrm{DB}=$ double blind; $\mathrm{PC}=$ placebo controlled; $\mathrm{Pla}=$ placebo; $\dot{\mathrm{CV}}=$ cardiovascular; $\mathrm{HR}=$ hazard ratio; $\mathrm{NYHA}=\mathrm{New}$ York Heart Association; $\mathrm{LVEF}=$ left ventricular ejection fraction; Carv = carvedilol; AEs = adverse events. ENECA= Efficacy of Nebivolol in the treatment of Elderly patient with Chronic heart failure as Add-on therapy to ACE inhibitors or angiotensin II receptor blockers, diuretics, and/or digitalis. SENIORS= Study of the Effects of Nebivolol Intervention on Outcomes and Rehospitalisation in Sequigerwith Heart Failure.

Nebivolol has been shown to be safe and effective in the treatment of hypertension in short and long term clinical trials. Recently report from a long-term (9 month) double blind, multicenter clinical trial, which recruited 845 patient with stage I to II hypertension comparing nebivolol monotherapy versus nebivolol in combination with other anti hypertensive therapies for the treatment of hypertension shows that it is safe and effective at doses 5 to $20 \mathrm{mg} /$ day in stage I to II hypertension and provides long term blood pressure lowering effect with favorable tolerability profile. ${ }^{23}$

Few clinical studies with nebivolol conducted in chronic heart failure patients. Table 2 summarizes the larger ones. The SENIORS (study of Effects of Nebivolol Intervention on Outcomes and Rehospitalisation in Seniors with heart failure) trial, a double blind placebo controlled study in the elderly heart failure patients $(n=2128)$ shows that nebivolol (at doses 1.25-10mg/day) was well tolerated and effective in reducing mortality and morbidity in patients of age $>70$ yrs with heart failure regardless of the initial ejection fraction. ${ }^{21,22}$
In a subanalysis of the SENIORS trial the effect of beta blockade with nebivolol were studied in 2111 elderly heart failure patients with impaired $(\mathrm{EF}<35 \%, \mathrm{n}=1359)$ and preserved $(E F>35 \%, n=752)$ left ventricular ejection fraction. The primary end point was all-cause mortality or cardiovascular hospitalizations. After 21 months follow up the effect of nebivolol was found to be similar in those with impaired and preserve ejection fraction. (HR 0.86: 95\% CI 0.72-1.04) in impaired EF and HR 0.81, 95\% CI 0.630.14 in preserved $\mathrm{EF} \mathrm{P}<0.48) .{ }^{19}$

A recent study shows that nebivolol also improves coronary micro vascular function (in patients with dilated cardiomyopathy) by increasing coronary flow reserve. ${ }^{14}$ This may have benefit in clinical settings like coronary artery disease and hypertension. In addition, nebivolol offers additional benefits by avoiding erectile dysfunction in male hypertensive patients (possibly as a result of its vasodilatory effect mediated by increased nitric oxide release) on long-term $ß$-adrenoreceptor antagonist therapy. ${ }^{12}$ 
In conclusion, nebivolol is a third generation highly selective $\aleph_{1}$-blocker with vasodilatory properties through enhanced nitric oxide production by vascular endothelium. Clinical studies demonstrated that nebivolol was as efficacious in reducing blood pressure as other ß-blockers, angiotensin-converting enzyme inhibitors, and calcium channel blockers. Preliminary clinical trials with nebivolol in heart failure also demonstrated beneficial effects in reducing rates of all-cause mortality and cardiovascular hospitalization. In addition, patients with asthma or COPD, or those who experience erectile dysfunction when using other ß-blockers may be benefited with nebivolol due to its high selectivity to $\beta_{1 \text { - }}$ receptor and enhanced nitric oxide producing properties.

\section{References}

1. Angelo Maffei, Alba Di Pardo, Rosa Carangi, Pierluigi Cariullo, Roberta, Poulet, Maria T. Genrila, Carmine Vacchione and Giuseppe Lembo. Nebivolol induces Nitric oxide release in the heart through inducible Nitric oxide release synthetase activation. Hypertersion 2007; 50; 652-56.

2. Billman GE, Castillo LC, Henseley J, Hohl CM, Altschuld RA. Beta 2-adrenergic receptor antagonists protect against ventricular fifrillation: in vivo and in vitro evidence for enhanced sensitivity to beta2-adrenergic stimulation in animals susceptible to sudden death. Circulation. 1997; 96: 1914-22.

3. Communal C, Singh k, Pemental DR. Colucci WS. Norepinephrine stimulates apoptosis in adult rat ventricular myocytes by activation of the beta adrenergic pathway. Circulation. 1998; 98: 1329-34.

4. Gao YS, Nagao T, Bond RA, Jannsens WJ, Vanhoutte PM. Nebivolol induces endothelium dependent relaxation of canine coronary artery. J cardiovasc Pharmacol. 1991; 17: 964-69.

5. Massion PB, Feron O, Dessy C, Balligand JL. Nitric oxide and cardiac function. Circ Res. 2003; 5:621-27

6. Poulet R, Marino G, Gentile Mt, Cifelli G, Lembo G. Nebivolol induced nitric oxide production through eNOS phosphorylation. Am J Hypertension; 2006; 19:579-86.

7. Nodari S. Metra M, Dei cas L. Beta-blocker treatment of patients with diastolic heart failure and arterial hypertension: a prospective, randomized, comparison of the long term effects of atenolol vs. Nebivolol. Eur J Heart Fail.2003; 5:62127.

8. Kemp O, Sieswerda GT, Visser CA. Comparison of effect on systolic and diastolic left ventricular function of Nebivolol vs. atenolol in patients with uncomplicated essential hypertension. Am J Cardol. 2003; 92:344-48.

9. Rozec B, quang TT. Noireaud J, Gauthier c. Mixed beta 3adrinoceptor agonist and alpha 1-adrinoceptor properties of Nebivolol in rat thoracic aorta. Br. J pharmacol. 2006: 147:699-706.

10. S.Ghio, G. Magrini, A. Serio, C. Klersy, A. Fucilli, A Ronaszeki, P. Karpati, G. Mordenti A. Capriati, P.A. Poole-Wilson and
L. Trvazzi. Effects of Nebivolol in elderly heart failure patients with or without systolic left Ventricular dysfunction result of the SENIORS echocardiographic substudy. European Heart journal: 2006: 147:699-706.

11. Enrico Agabiti Rosci and Damiano Rizzoni. Metabolic profile of Nebivolol, a ß adrenoceptor Antagonist with Unique Characteristics; Drugs; 2007: 67(8) : 1097-1107.

12. K Brixuus, M Middeke, A Lichtenthal, E Jang R H G schwinger. Ntiric Oxide, Erectile Dysfunction and Beta-Blocker Treatment (MR NOED Study) : Benefit of Nebivolol Versus Metoprolol in Hypertensive men. Clinical and Experimental pharmacology and physiology; 2007: 34:327-31.

13. Mario Togri, Francesco Vigorito, Stephen Windecker, Linda Abrecht, Peter Wcnaweser, Stephane Cook, Michael Billinger, Bernhard Meier, Otto M. Hess. Does the ß-Blocker Nebivolol Increase Coronary Flow Reserve? Cardiovasc Drugs Ther. 2007; 21: 99-108.

14. Eli I. Lev, Alexander Battler. Unique Effect of Nebivolol on Coronary Hemodynamics: It's All a Matter of Flow; Cardiovasc Drug Ther. 2007; 21: 75-76.

15. Alberto zanchetti. Nebivolol in hypertension and chronic heart failure: A view point Drugs. 2006; 66 (10): 1410.

16. Marit D. Mien and Antona J. Wagstaff. Nebivolol: A review of its use in the management of hypertension and chronic heart failure. Drugs 2006; 66(10): 1389-409.

17. Adriana Georgescu, Doina Popov, Wmanuel Dragan, Elena Dragemir, Elisabeta Badila. Protective effects of Nebivolol and reversal of endothelial dysfunction in diabetes associated with hypertension. European Journal of Pharmacology 2007; 570: 149-58.

18. G. Mereauoglu, It. Uzun, F. Mercanoglu, M. Gurgor. Nitric oxide mediated effect of Nebivolol on cardiomyocyte apoptosis after myocardial infraction in rats. Poster display III Myocardial infarction 10 June 2007, P-64.

19. Ulisse Garbin, Anna Fratta Pasini, Chiara Stranieri Manfro, Veronica Bocciolefti, Luciano Comisacini. Nebivolol reduces asymmetric dimethyl arginine in endothelial cells by increasing dimethylarginine dimethylaminohydrolase2(DDAH2) expression and activity. Pharmacological Research 2007; 56:515-21.

20. C. Reidenbach, R..H.G. Schwinger, D. Steinritz, K. Kene, H. Thiermann, T. Klotz, F. Sommer, W. Bloch, K. Brixius. Nebivolol induces eNOS activation and NO- liberation in murine corpus cavernosum. Life Science2007;80: 2471-77.

21. Dirk J. van Veldhuisen, Alain Cohen-Solal, Michael Bohm, Stefan D. Anker, et al. Beta-Blockade with Nebivolol in Elderly Heart Failure Patients With Impaired and Preserved Left Ventricular Ejection Fraction. Data From SENIORS (Study of Effects of Nebivolol Intervention on Outcome and Rehospitalazation in Seniors With Heart Failure). J Am Coll Cardiol 2009; 53: 2150-58

22. Cheng JWM. Nebivolol: a third generation beta-blocker for hypertension. Clinical Therapeutics 2009;31(3):447-62.

23. Wojciechowski David; Papademetriou Vasilios Beta-blockers in the management of hypertension: focus on nebivolol. Expert review of cardiovascular therapy 2008;6(4):471-79. 